Syntax Fusion : Jurnal Nasional Indonesia

p-ISSN: -

e-ISSN : 2775-4440

Vol. 1, No. 3, Maret 2021

\title{
PENGEMBANGAN ASPEK KOGNITIF DALAM MENGENAL LAMBANG BILANGAN, HURUF VOKAL DAN KONSONAN
}

\author{
Maimun Karyati \\ Universitas Negeri Makasar \\ Email: maimunkaryati1984@gmail.com
}

\begin{abstract}
Abstrak
Aktivitas guru dalam mengelola pembelajaran pada materi tentang mengenal huruf vokal dan konsonan melalui model make a match pada anak kelompok B di TK Mekar sari terlaksana dengan sangat baik. Hal ini dapat dilihat dari siklus I dan pada siklus II mengalami peningkatan sebagai berikut : pada siklus I guru memperoleh skor 82,50\%. Sedangkan pada siklus II guru memperoleh skor 90,00\%.

Hasil evaluasi anak dalam mengikti proses pembelajaran pada materi mengenal huruf vokal dan konsonan melalui model make a match anak mengalami peningkatan yang sangat baik. Hal ini dapat dilihat dari siklus I dan pada siklus II sebagai berikut : Pada siklus I yang mendapatkan nilai Belum Berkembang (BB) 0 anak dengn skor rata-rata 00,00\% dan yang mendapatkan nilai Mulai Berkembang (MB) adalah lanak dengan skor rata-rata 20,00\% dan yang mendapatkan nilai Berkembang Sangat Harapan (BSH) adalah 4 anak dengan skor 80,00\%. Pada siklus II yang mendapatkan nilai Berkembang Sesuai Harapan (BSH) adalah 2 anak dengan skor rata-rata 50,00\% dan yang mendapatkan nilai Berkembang Sangat Baik (BSB) adalah 2 anak dengan skor rata-rata 50,00\%.

Dengan melihat hasil presentasi tersebut dari siklus I sampai dengan siklus II maka kegiatan mengenal huruf vokal dan konsonan melalui model make a match kegiatan pembelajaran mengalami peningkatan yang sangat baik.
\end{abstract}

Kata kunci: Profesi Guru, Pendidikan, Pengalaman Lapangan.

\section{Pendahuluan}

Undang Undang Republik Indonesia tahun 2003 menyatakan dengan jelas bahwa fungsi dan tujuan Pendidikan nasional bangsa Indonesia sebagaimana tercantum dalam BAB II pasal 3 yaitu Pendidikan nasional berfungsi mengembangkan kemampuan dan membentuk watak serta peradaban bangsa yang bermartabat dalam rangka mencerdaskan kehidupan bangsa bertujuan untuk berkembangnya potensi peserta didik agar menjadi manusia yang beriman dan bertakwa kepada Tuhan Yang Maha Esa berakhlaq mulia sehat 
berilmu cakap kreatif mandiri dan menjadi warga negara yang demokratis serta bertanggung jawab.

Pendidikan anak usia dini hakekatnya adalah pendidikan yang di selenggarakan dengan tujuan untuk memfasilitasi pertumbuhan dan perkembangan anak secara menyeluruh atau menekankan pada seluruh aspek kepribadian anak. Pendidikan anak usia dini memberikan kesempatan kepada anak usia dini khususnya TK perlu menyediakan berbagai kegiatan yang dapat mengembangkan berbagai aspek perkembangannya yang meliputi kognitif , bahasa sosial emosional fisik motorik ( aderson 1993 ) dalam bukunya masihtoh ( 2005, hal1-7 )Manusia diciptakan oleh tuhan sebagai mahluk yang istimewa karena manusia memiliki akal dan fikiran. Kedua hal inilah yang membedakan manusia dengan mahluk lainnya.

Sebagai upaya mencapai harapan tersebut pendidik merupakan sarana dan wadah yang paling tepat untuk mewujudkan semua itu.Dalam pengembangan semua aspek itu tentunya memerlukan arahan yang tepat dari pendidik.Kenyataan yang terjadi dilapangan terutama di TK. Mekar sari dari 15 orang siswa nilai kognitif dalam mengenal lambang bilangan huruf vokal dan konsonan hanya 4 orang yang memiliki bintang 3 hanya 9 orang yang memiliki bintang 2 dan 2 orang yang memiliki bintang 2 .

Berdasarkan latar belakang tersebut peneliti melakukan penelitian tindakan kelas yang berjudul "Pengembangan Aspek kognitif dalam mengenal lambang bilangan, Huruf Vokal dan Konsonan".

\section{Metode penelitian}

Di dalam penelitian ini menggunakan bentuk guru sebagai peneliti, dimana guru memili peran yang sangat penting dalam penelitian tindakan kelas. Dalam hal ini, tujuan yang utama dari penelitian tindakan kelas ini adalah untuk meningkatkan prakti-praktik proses pembelajaran didalam kelas. Di dalam kegiatan ini, guru terlibat secara langsung sepenuhnya dalam proses perencanaan, tindakan, observasi dan refleksi. Kehadiran dari pihak lain dalam penelitian ini tidak memiliki peran yang dominan dan bahkan sangat kecil.

Adapun penelitian ini mengacu pada perbaikan pembelajaran yang berkesinambungan. (Suharsimi Arikunto, 2006) menyatakan bahwa model penelitian tindakan adalah berbentuk spiral. Tahapan penilaian tindakan pada suatu siklus meliputi perencanaan atau pelaksanaan obervasi dan refleksi. Siklus ini akan terus berlanjut dan akan dihentikan jika sesuai dengan kebutuhan dan dirasa sudah mencapai tujuan belajar.

Penelitian ini merupakan penelitian tindakan ( action research ) karena penelitian ini juga termasuk dalam penelitian deskriptif, karena menggambarkn bagaiman suatu tehnik pembelajaran diterapkan dan bagaimana hasil yang diinginkan dapat dicapai.

Menurut Suharsimi Arikonto, ada empat macam bentuk penelitian tindakan, yaitu (1) penelitian tindakan guru sebagai peneliti, (2) penelitian tindakan kolaboratif, (3) penelitian tindakan simulatif terinteratif dan (4) penelitian tindakan sosial eksperimental. Ada beberapa ahli yang mengemukakanmodel penelitian tindakan kelas dengan bagan yang berbeda, tetapi secara garis basarnya terdapata empat tahapan yang lazim didahului, 
yaitu perencanaan, pelaksanaan, pengmatan, dan refleksi. (Suharsimi Arikunto, 2006: 104)

\section{Hasil dan Pembahasan}

Pelaksanan Penelitian Tindakan Kelas Siklus I

Pelaksanaan Penelitian Tindakan Kelas Pertemuan Pertama

\section{a. Perencanaan}

$>$ Membuat rencana pelaksanaan pembelajaran harian( RPPH)

$>$ Membuat Lembar Kerja Peserta Didik (LKPD)

$>$ Membuat Media yang akan digunakan dalam penelitian

$>$ Menyiapkan kamera

\section{b. Pelaksanaan}

Pada siklus I pertemuan pertama yang dilaksanakan pada tanggal 22-Oktober2020, peneliti mengajarkan materi tentang pengembangan pengenalan lambang bilangan huruf vokal dan konsonan anak melalui model Make A Match. Adapaun skenario dari pelaksanaan tindakan pertemuan pertama adalah sebagai berikut :

1) IndikatorPencapaian Perkembangan

$>$ Pengenalan huruf Vokal dan konsonan

2) Tujuan pembelajaran

> Anak dapat mengenal huruf vokal dan konsonan

3) Kegiatan pembelajaran

Adapun kegiatan pembelajaran yang dilakukan dengan tahapa sebgai berikut :

a) Kegiatan pembukaan

$>$ Guru membuka pertemuan dengan mengucapkan salam,dan menanyakan kabar kepada anak

Guru memberikan penjelasan tentang materi dan memeriksa kesiapan , menyampaikan tema pembelajaran serta tanya jawab terhadap anak .

b) Kegiatan Inti

> Kegiatan inti dilaksanakan dengan melakukan pembelajaran dalam mengenal huruf vokal dan konsonan melalui model Make A Match. Kemudian anak istirahat selama kurang lebih 15 menit diisi dengan mencuci tangan doa sebelum makan doa sesudah makan dan bermain bebas.

c) Kegiatan Penutup

$>$ Guru menanyakan perasaan anak selama proses belajar dan berkegiatan

$>$ Guru dan anak membuat kesimpulan tentang kegiatan yang sudah dilaksanakan

Guru memberikan informasi kepada anak tentang materi pada pertemuan esok hari

$>$ Guru mengajak anak untuk berdoa bersama untuk mengahiri kegiatan. 


\section{c. Hasil pengamatan}

Berdasarkan hasil pengamatan pada tabel 4.1 pada siklus I pertemuan ke lima dapat disimpulakn bahwa aktivitas guru kepada anak dalam proses pembelajaran melalui kegiatan menggunting gambar pola kategori baik, hal ini dapat terlihat dari rata-rata nilai yang diberikan oleh pengamat dengan nilai skor keterlaksanaan akhir yaitu 82,50\%. Dengan perincian kegiatan awal memperoleh skor 83,33\%, kegiatan inti 87,50\% dan kegiatan akhir memperoleh skor $78,12 \%$. Secara lebih jelas dapat dilihat pada grafik berikut:

Grafik 4.1 observasi aktivitas guru siklus I pertemuan pertama

\begin{tabular}{lllll}
\hline 90 & & & & \\
80 & & & & \\
70 & & & & \\
& & & & \\
\hline
\end{tabular}

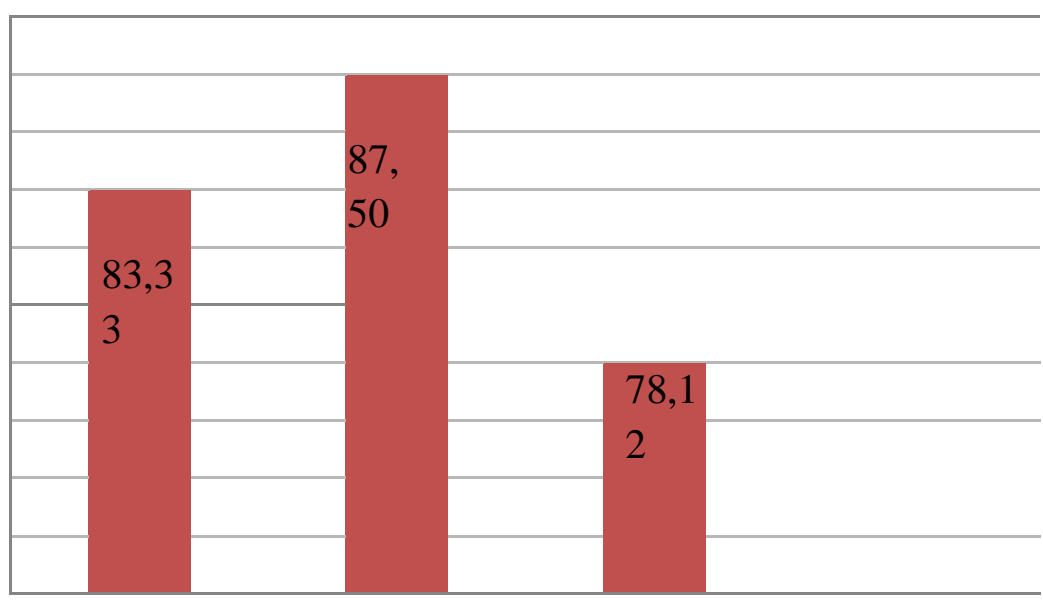

1. Observasi hasil belajar anak siklus 1 pertemuan pertama

Berdasarkan hasil pembelajaran yang tekah dilaksanakan, secara umum pemahaman anak pada siklus I pertemuan pertama terlihat mulai berkembang. Hal ini dapat dilihat pada tabel di bawah ini :

\begin{tabular}{lllllll}
\hline NO & NAMA & INDIKATOR & BB & MB & BSH & BSB \\
& & PENGEMBANGAN & & & & \\
\hline 1 & Yusuf & Mengenal huruf & & & $\sqrt{ }$ & \\
& & & & & \\
& & & & & \\
& &
\end{tabular}


Maimun Karyati

\begin{tabular}{|c|c|c|c|c|}
\hline 2 & Mada & $\begin{array}{l}\text { Mengenal } \\
\text { Vokal } \\
\text { Konsonan }\end{array}$ & $\begin{array}{r}\text { huruf } \\
\text { dan }\end{array}$ & $\sqrt{ }$ \\
\hline 3 & Jannah & $\begin{array}{l}\text { Mengenal } \\
\text { Vokal } \\
\text { Konsonan }\end{array}$ & $\begin{array}{r}\text { huruf } \\
\text { dan }\end{array}$ & $\sqrt{ }$ \\
\hline 4 & Wawa & $\begin{array}{l}\text { Mengenal } \\
\text { Vokal } \\
\text { Konsonan }\end{array}$ & $\begin{array}{r}\text { huruf } \\
\text { dan }\end{array}$ & $\sqrt{ }$ \\
\hline 5 & Fiona & $\begin{array}{l}\text { Mengenal } \\
\text { Vokal } \\
\text { Konsonan }\end{array}$ & $\begin{array}{r}\text { huruf } \\
\text { dan }\end{array}$ & $\sqrt{ }$ \\
\hline
\end{tabular}

Keterangan Nilai:

- BB : Belum Berkembang

- MB : Mulai Berkembang

- BSH : Berkembang sesuai harapan (bila anak sudah mampu mencapai indicator sesuai dengan harapan guru

- BSB : Berkembang sangat baik (anak mampu mencapai indicator secara mandiri dan sudah membantu temannya)

Untuk lebih jelasnya dapat di lihat pada grafik 4.2 di bawah ini :

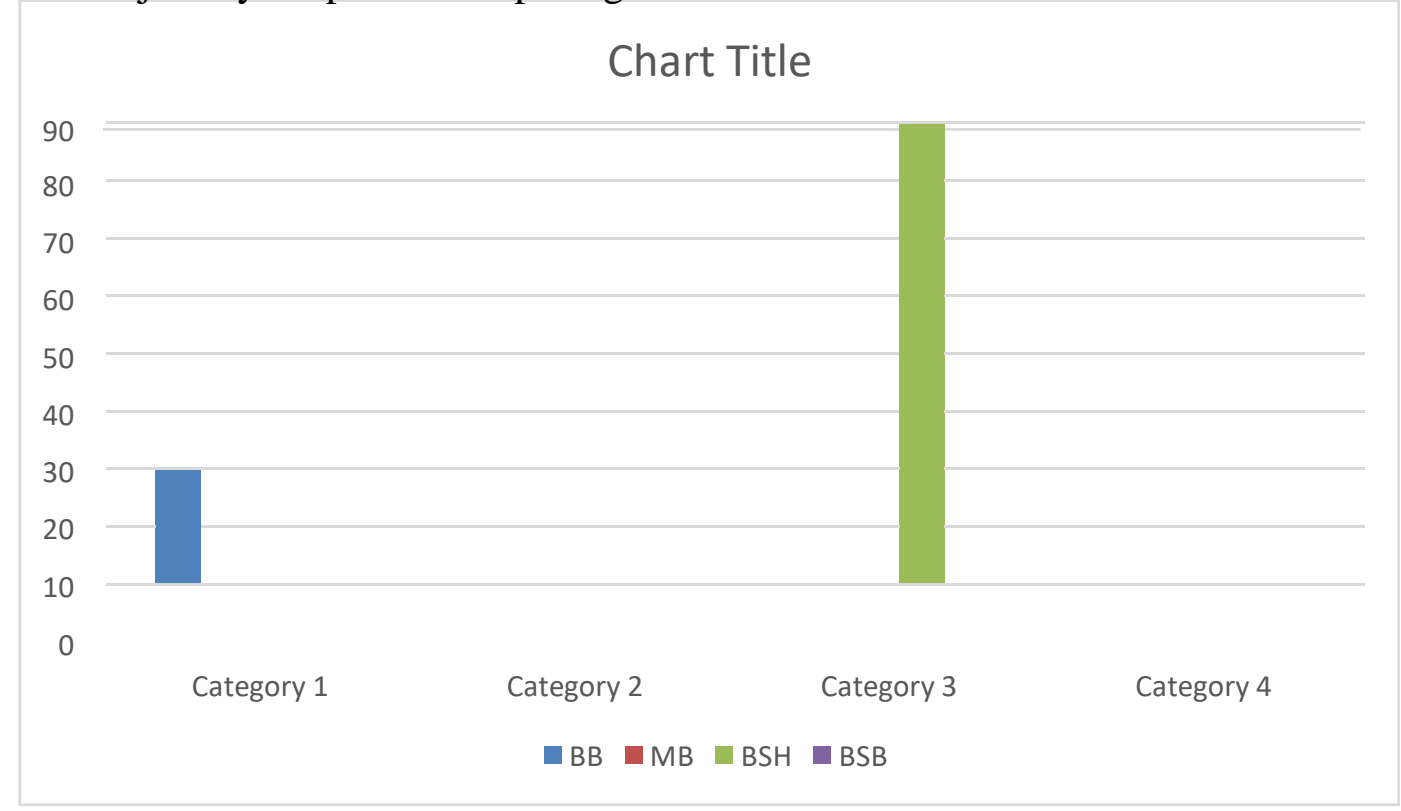


Berdasarkan hasil observasi dapat diambil kesimpulan bahwa kegiatan pembelajaran yang sudah dilaksanakan pada siklus 1 pertemuan pertama ada beberapa catatan yang perlu diperbaiki yaitu hasil evaluasi anak yang Belum Berkembang ( BB )ada 0 anak dan jumlah anak yang Mulai Berkembang ( MB ) sedangkkan anak yang Berkembang Sangat Baik ( BSH ) berjumlah 3 anak. Untuk itu peneliti harus lebih meningkatkan lagi proses pembelajaran agar lebih meningkatkan hasilnya pada pertemuan selanjutnya.

B. Pelaksanaan Penelitian Tindakan Kelas Siklus II

1. Pelaksanaan Penelitian Tindakan Kelas Pertemuan Pertama

a. Perencanaan

$>$ Membuat rencana pelaksanaan pembelajaran harian( RPPH)

$>$ Membuat Lembar Kerja Peserta Didik (LKPD)

$>$ Membuat Media yang akan digunakan dalam penelitian

$>$ Menyiapkan kamera

b. Pelaksanaan

Pada siklus II pertemuan pertamayang dilaksanakan pada tanggal 2-November2020 peneliti mengajarkan materi tetang pengenalan huruf vokal dan konsonan. Pertemuan pertama pada siklus II adalah sebagai berikut :

1) Indikator Pencapaian Perkembangan

Mengenal huruf vokal dan konsonan

2) Tujuan pembelajaran

Anak dapat mengenal huruf vokal dan konsonan melalui model make a match

3) Kegiatan pembelajaran

> Guru membuka pertemuan dengan mengucapkan salam,dan menanyakan kabar kepada anak

$>$ Guru memberikan penjelasan tentang materi dan guru mengajak anak berdoa sebelum belajar.Guru melakukan absensi. Kemudian menyampaikan tema pembelajaran dan meminta anak untuk selalu berprilaku baik. kegiatan yang akan dilaksanakan guru mempersiapkan kartu kata dan jawaban yang sesuai dengan tujuan pembelajaran.guru menjelaskan langkah 1;angkah aturan permainan.Guru membagi anak dalam kelompok, guru membagikan kartu kepada anak satu bagian kartu soal dan satu bagian kartu jawaban.Masing masing anak mendapat satu kartu anak di beri kesempatan untuk memikirkan jawaban dari kartu yang ia pegang, Kemudian anak di minta mencari pasangannya yang cocok dengan kartunya.

b) Kegiatan Inti

$>$ kegiatan yang akan dilaksanakan guru mempersiapkan kartu kata dan jawaban yang sesuai dengan tujuan pembelajaran.guru menjelaskan langkah 1;angkah aturan permainan.Guru membagi anak dalam kelompok, 
guru membagikan kartu kepada anak satu bagian kartu soal dan satu bagian kartu jawaban.Masing masing anak mendapat satu kartu anak di beri kesempatan untuk memikirkan jawaban dari kartu yang ia pegang, Kemudian anak di minta mencari pasangannya yang cocok dengan kartunya.

c) Kegiatan Penutup

$>$ Guru menanyakan perasaan anak selama proses belajar dan berkegiatan

$>$ Guru dan anak membuat kesimpulan tentang kegiatan yang sudah dilaksanakan

Guru memberikan informasi kepada anak tentang materi pada pertemuan esok hari

$>$ Guru mengajak anak untuk berdoa bersama untuk mengahiri kegiatan.

c. Hasil Pengamatan/ Observasi

1. Observasi Aktivitas Guru

Hasil observasi aktivitas guru selama melaksanakan proses pembelajaran yang dilakukan adalah sebagai berikut:

Tabel 4.15 Observasi Aktivitas Guru Siklus II Pertemuan Pertama

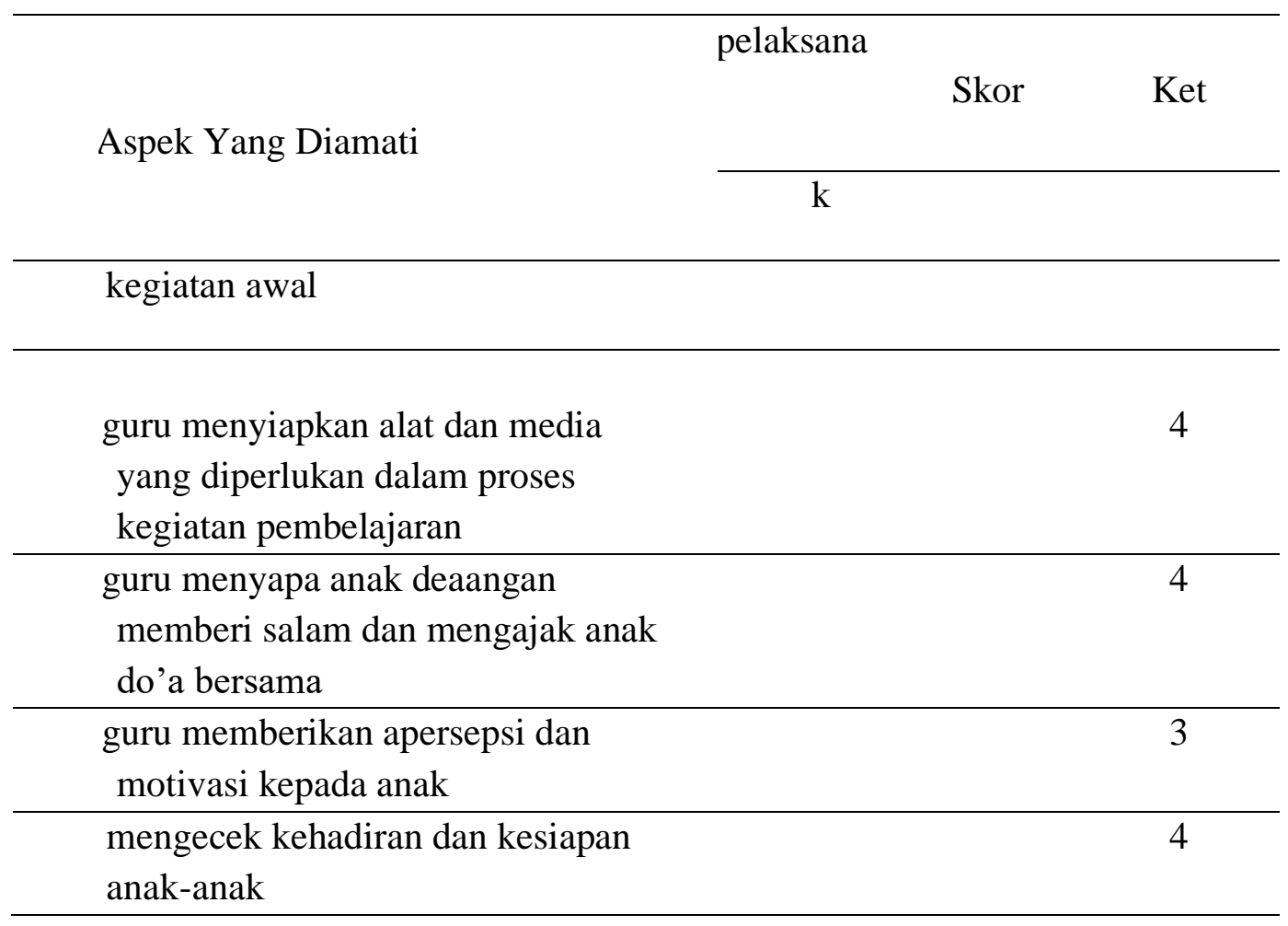


Berdasarkan hasil pengamatan pada tabel 4.3 pada siklus II pertemuan pertama dapat disimpulakn bahwa aktivitas guru kepada anak dalam proses pembelajaran melalui kegiatan menggunting gambar pola dilakukan dengan kategori sangat baik, hal ini dapat terlihat dari rata-rata nilai yang diberikan oleg pengamat dengan nilai skor keterlaksanaan akhir yaitu 90,00\%. Dengan perincian kegiatan awal memperoleh skor 91,60\%, kegiatan inti $91,66 \%$ dan kegiatan akhir memperoleh skor $87,50 \%$. Secara lebih jelas dapat dilihat pada grafik 4.3 berikut:

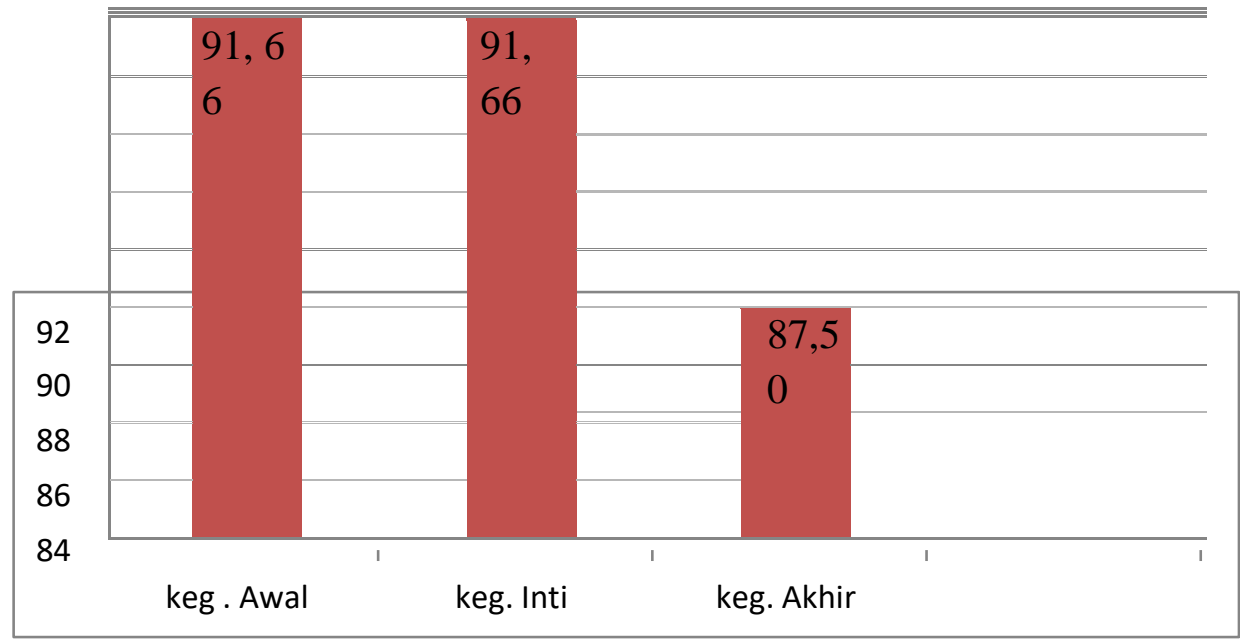

2. Observasi Hasil Belajar Anak

Berdasarkan hasil observasi pembelajaran yang telah dilaksanakan, secara umum pemahaman anak pada siklus II pertemuan pertama terlihat Berkembang Sesui Harapan ( BSH ). Hal ini dapat dilihat pada tabel di bawah ini :

\begin{tabular}{|c|c|c|c|c|c|}
\hline $\mathrm{NO}$ & NAMA & $\begin{array}{c}\text { INDIKATOR } \\
\text { PENGEMBANGAN }\end{array}$ & BB $\mathrm{MB}$ & $\mathrm{BSH}$ & BSB \\
\hline 1 & Yusuf & $\begin{array}{l}\text { Mengenal huruf } \\
\text { Vokal dan Konsonan }\end{array}$ & & & $\sqrt{ }$ \\
\hline 2 & Mada & $\begin{array}{l}\text { Mengenal huruf } \\
\text { Vokal dan } \\
\text { Konsonan }\end{array}$ & & $\sqrt{ }$ & \\
\hline 3 & Jannah & $\begin{array}{l}\text { Mengenal huruf } \\
\text { Vokal dan } \\
\text { Konsonan }\end{array}$ & & & $\sqrt{ }$ \\
\hline 4 & Wawa & $\begin{array}{l}\text { Mengenal huruf } \\
\text { Vokal dan } \\
\text { Konsonan }\end{array}$ & & $\sqrt{ }$ & \\
\hline
\end{tabular}




\begin{tabular}{|c|c|c|c|c|c|}
\hline 5 & Fiona & & & & \\
\hline & Jumlah & - & - & 2 & 2 \\
\hline \multirow{2}{*}{\multicolumn{2}{|c|}{ Presentasi }} & 0 & 0 & 50,00 & 50,00 \\
\hline & & $\%$ & $\%$ & $\%$ & $\%$ \\
\hline
\end{tabular}

Keterangan :

BB : Belum

Berkembang MB

: Mulai

Berkembang

BSH : Berkembang

Sesuia Harapan BSB :

Berkembang Sangat Baik

Untuk lebih jelasnya dapat di lihat pada grafik 4.4 di bawah ini :

Berdasarkan hasil observasi dapat diambil kesimpulan bahwa kegiatan pembelajaran yang sudah dilaksanakan pada siklus II pertemuan pertama perkembangan anak mencapai ketuntasan yaitu ada 1 (20,00\%) anak yang Berkembang Sesuia Harapan ( BSH ) sedangk kan anak yang Berkembang Sangat Baik ( BSB ) berjumlah 4 anak ( $80,00 \%$ ). Sehingga pada siklus II anak mencapai ketuntasan $100 \%$

C. Pembahasan

1. Aktivitas Guru

Dalam pelaksanaan pengembangan aspek kognitif dalam mengenal huruf vokal dan konsonan melalui model make a match membuat anak bisa lebih baik .Guru mengecek kehadiran anak materi sudah mulai ada peningkatan.Guru melibatkan anak

Berdasarkan hasil observasi dapat menunjukkan adanya peningkatan dalam pengelolaan pembelajaran yang dilaksanakn oleh guru, hal ini disebabkan pelaksanaan pembelajaran dilaksanakan dengan baik serta motivasi yang baik, menerapakan kegiatan model Make a Match dalam proses pembelajaran untuk meningkatkan kemampuan kognitif mengenal huruf vokal dan konsonan anak.

2. Hasil Belajar Anak

Hasil evaluasi anak dalam pengembangan kemampuan kognitif anak dalam mengenal huruf vokal dan konsonan pada siklus I pertemuan pertama yang Belum Berkembang ( BB ) ada 0 anak ( $00.00 \%$ ) dan jumlah anak yang Mulai Berkembang ( MB ) berjumlah 0 anak ( 00,00\% ) sedangkkan anak yang Berkembang Sangat Baik ( BSH ) berjumlah 4 anak (80,00\% ). Dan Berkembang sangat Baik (BSB ) berjumlah 1 anak (20\%)Sedangkan pada siklus II pertemuan pertama perkembangan anak mencapai ketuntasan yaitu ada 1 anak (20,00\% ) mulai berkembang( MB ) sedangkkan anak yang Berkembang Sangat Baik ( BSH ) ada 4 anak ( 80,00\% ).

Dari hasil pengamatan di atas menunjukkan adanya peningkatan dalam 
kemampuan kognitif anak dalam mengenal huruf vokal dan konsonan melalui model make a match.

\section{Kesimpulan}

Dengan mencermati hasil-hasil dari penelitian dapat di simpulkan bahwa Aktivitas guru dalam mengelola pembelajaran pada materi tentang mengenal huruf vokal dan konsonan melalui model make a match pada anak kelompok B di TK Mekar sari terlaksana dengan sangat baik. Hal ini dapat dilihat dari siklus I dan pada siklus II mengalami peningkatan sebagai berikut : pada siklus I guru memperoleh skor $82,50 \%$. Sedangkan pada siklus II guru memperoleh skor $90,00 \%$.

Hasil evaluasi anak dalam mengikti proses pembelajaran pada materi mengenal huruf vokal dan konsonan melalui model make a match anak mengalami peningkatan yang sangat baik. Hal ini dapat dilihat dari siklus I dan pada siklus II sebagai berikut : Pada siklus I yang mendapatkan nilai Belum Berkembang (BB) 0 anak dengn skor ratarata 00,00\% dan yang mendapatkan nilai Mulai Berkembang (MB) adalah 1anak dengan skor rata-rata 20,00\% dan yang mendapatkan nilai Berkembang Sangat Harapan (BSH) adalah 4 anak dengan skor 80,00\%. Pada siklus II yang mendapatkan nilai Berkembang Sesuai Harapan (BSH) adalah 2 anak dengan skor rata-rata 50,00\% dan yang mendapatkan nilai Berkembang Sangat Baik (BSB) adalah 2 anak dengan skor rata-rata $50,00 \%$.

Dengan melihat hasil presentasi tersebut dari siklus I sampai dengan siklus

II maka kegiatan mengenal huruf vokal dan konsonan melalui model make a match kegiatan pembelajaran mengalami peningkatan yang sangat baik. 
Maimun Karyati

Biliografi

Yuliani nurani Sujiono, dkk, 2009, Metode Pengembangan Kognitif, Jakarta, Universitas Terbuka

UUD RI No. 20, Tahun 2003, tentang Sistem pendidikan Nasional dan penjelasannya cemerlang

Masihtoh dkk, (2005 ) Strategi tk, Jakarta : 2005

Arikunto suharsimi dkk.2010. Penelitian Tindakan kelas 